\title{
An Empirical Investigation of the Volatility Spill-over and Asymmetries between Nifty Index and Rupee- Dollar Exchange Rate
}

\author{
Rakesh Shahani ${ }^{* *}$ and Prateek Tomar ${ }^{2}$ \\ 'Associate Professor, Department of Business Economics, Dr. Bhim Rao Ambedkar College, University of Delhi, \\ New Delhi - 110094, Delhi, India; rakesh.shahani@gmail.com \\ 2Pursuing Post Graduate Diploma in Management (PGDM) from Birla Institute of Management Technology \\ (Bimtech), Greater Noida - 201306, Uttar Pradesh, India; prateekinovate@gmail.com
}

\begin{abstract}
The present study is an attempt to investigate the conditional volatility of returns of the two major segments of Indian financial markets viz. Re/\$ Exchange Rate and Nifty Index Stock Index using GARCH (p,q) methodology. The period of the study has been taken to be April 2007-March 2017 and the data has been collected as monthly closing prices of the two variables, namely rupee dollar exchange rate and NSE Nifty. The analysis has been carried on first differenced (log transformed) prices. For studying the spill-over of volatility from a market to another, squared residuals (after standardization) from another market have been included as variance regressors. Further to find out whether or not there was any asymmetric returns of the markets under study, Threshold GARCH (T-GARCH) Model has been employed. The results of the study revealed the presence of conditional volatility of returns. The optimal model was identified as ARCH (1) when Re/\$ Exchange Rate was the dependent variable while it was GARCH $(1,1)$ when Nifty Index was taken as dependent variable. The bi-directional volatility spill-over (contemporaneous) was clearly evident by the two models and the same was captured by the variance regressors i.e. the standardized squared residuals. Further the results showed no sign of any asymmetry in volatility as reflected by the T-GARCH coefficients.
\end{abstract}

Keywords: Volatility Spill-over, AR (1)-GARCH (p,q), T-GARCH, Asymmetric Returns, B-P-G Heteroscedasticity Test JEL classification: G1, G15

\section{Introduction}

If two important segments of financial markets, viz. Gold and Stock markets are known to move in opposite direction, there are many other segments which are known to move in tandem and two of these segments are foreign exchange and stock markets. There are a number of reasons behind co-movement between these two markets; first being the role of corporate earnings especially of those companies which have revenues from exports. Such Companies respond in a big manner to changes in the exchange rate which in turn impacts their stock prices. (Kim) 1 . Second reason is the role of globalization and international diversification by investing community which has resulted in transmission of volatility both within and across markets. According to King and Wadhwani ${ }^{2}$ 'contagion' effect is very common across markets and a market is known to overreact to the event of another market. We have witnessed this 'contagion' effect during the Sub Prime crisis in 2008-09, when almost all the major stock markets reacted for an event which was restricted to few developed economies. This clearly shows that today's economies enjoy fair amount of integration (both in terms of trade and finance) than what was during the $80 \mathrm{~s}$ and $90 \mathrm{~s}$ (Balli et al.) $)^{3}$. If we examine the movement of the two markets, we find that before 1990s, the degree of co-movement across markets was rather slow (Hilliard) ${ }^{4}$ and the noticeable increase

${ }^{*}$ Author for correspondence 
in co-movement of global equity markets could only be seen post 1990s. This has also lead to a general shift in the nature of studies on these two markets over the years; whereas initial studies focused on general aspects of co-integration, latter studies emphasized on integration between local markets with global markets, and more recent studies seem to have shifted to regime specific integration.

From the theoretical perspective, macro-economic researchers on inter-linkages between currency markets and stock markets have primarily focused on two popular views; the flow based model of Dornbusch and Fischer ${ }^{5}$ and the stock oriented model of Branson ${ }^{6}$, Frankel ${ }^{7}$ and

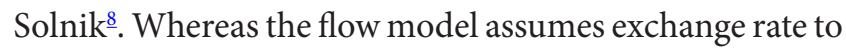
be a function of trade balance and performance on current account and thus becomes the guiding force for the stock prices, the stock oriented model assumes exchange rate to be a determinant of demand and supply of equities (and bonds to a some extend). When we examine the two models we find that the two are also interlinked. This is so because a rise in prices of stocks result in rise in domestic rates leading to a fall in exchange rate or depreciation of currency. This thus pushes up exports thereby resulting in higher stock prices and the cycle goes on. Some other theories have also been developed explaining the interlinkages between stock and foreign exchange markets like the one given by Kutty ${ }^{9}$ where the author is of the opinion that in case domestic interest rates are low (and also the stock prices), there is a flight of capital out of the country thereby resulting in depreciation of local currency. Thus low stock prices/low interest rates result in currency depreciation.

Over the years, researchers have investigated empirical relation between stock markets and exchange rate from different angles i.e. prior to 1990s the relation focused on contemporaneous relation between the two variables and studies like Aggarwal ${ }^{10}$, Soenen and Hennigar ${ }^{11}$ have shown this relation by correlating foreign exchange and stock markets. Later, the research shifted on examining the causality relation between the two variables, and the prominent studies include a study by Bahmani et al., $\underline{12}$ where they could find causality to be bi-directional between stock index and exchange rates. On the other hand Kutty ${ }^{2}$ for Mexico showed that causality was unidirectional flowing from stocks to exchange rates. Ajayi et al.,,$\frac{14}{}$ could find bi-lateral causality for developed economies and no causality for emerging markets. Another dimension explored with respect to these two variables has been to develop short and long run relation amongst the variables. A study by Ajayi and Mougoue $\frac{13}{3}$ could find short and long term linkages for their sample of eight industrial nations, Nieh and Lee $e^{15}$ in their study on G-7 nations could find only shortrun dynamics but no long-run relationship between these variables. Yet another approach has been to study transmission of volatility (i.e. volatility spill-over) from stock markets to currency markets and vice versa. Under this approach most researchers have adopted GARCH based methodology which was developed by Engle ${ }^{16}$ and Bollerslev ${ }^{17}$. Several researchers have focused on different variants of GARCH such as E-GARCH, T-GARCH, and BEKK models.

Considering the above aspects, the main objective of this paper is to identify the volatility spill-over between stock market and exchange rate of India and the data for this purpose is taken as ten year monthly log returns for period 1st April 2007 to March 31st 2017.The spill-over between the two markets has been tested using AR(1)GARCH (p,q) approach. The asymmetry in the volatility spill-over equation has been tested by another variant of GARCH namely T-GARCH. The rest of the paper is structured as follows: Section 2 reviews the existing literature on the inter-play between exchange rate and stock prices with a special focus on India related studies. Section 3 describes the data sources and provides a brief outline of econometric tools used under the study. Section 4 provides methodology and different hypothesis established under the study. Section 5 gives the empirical results and interpretation of these results and finally we have last two sections; Section 6 which gives the conclusion and policy implications followed by Section 7 as references.

\section{Review of Literature}

Under this section we focus our attention on a mix of relevant papers which have followed various approaches in exploring the relation between exchange rate and stock markets with an inclination towards Indian sub-continent related papers.

Polisetty et al.,18 analysed the movement between Indian Stock Index and Rupee-Dollar exchange rate for the period 2005-2014. The results which were based upon simple techniques of correlation and regression showed that the strength of association amongst the two variables was very low; with low positive coefficient of correlation amongst the variables at +0.433 . Another study on Indian 
Markets was carried out by Poornima et al., $\frac{19}{}$ where they applied Granger Causality to test for the causal relationship between Nifty Index returns and returns on Rupee Dollar Exchange Rate for the period July 2014-July 2016 by taking daily closing prices on the two variables. The study found unidirectional relationship flowing from Exchange Rate to NSE Nifty, however the correlation between the two variables was found to be negative. On the other hand a study by Agrawal et al., $\underline{20}$ obtained somewhat different results from their causality model; their results showed unidirectional relationship running from Nifty Index to rupee exchange rate. Another interesting result was seen in Gulati et al., $\underline{21}$ where they too applied causal relation between Indian stock markets and foreign exchange markets but found no causality between the markets. Their study took two major indices viz. the Nifty and BSE Sensex for the period 2004-2012, however neither of them could prove causal relation with the exchange rate. The coefficient of correlation was also found to be low but was positive amongst the variables.

On the other hand some researchers have actually carried out more specific studies like Balli et al., $\frac{3}{-}$ where they tested the co-integration dynamics between equity markets of Asia, Middle East and few developed countries with the intention to test the equity returns and volatility spill-over across markets. Their target was to focus only on spill-over and the results did give a positive indication with respect to spill-overs from developed to emerging markets, however there was a considerable deviation in the magnitude of the shocks. The factors explaining the return and volatility spill-over were identified as country's bilateral trade, stock market trends in terms of market cap and foreign portfolio investment, past colonial history and physical distance. Another specific study focused on the period of financial crisis and was carried out by Mozumder et al.,22 where they tested for the volatility spill-over between stock markets and foreign exchange market for selected emerging and developed nations during pre and post - crisis periods using E-GARCH model. The results showed uni-directional volatility spillover from stocks markets to exchange rates in developed nations and just the opposite in case of emerging markets (except Brazil where it was bi-directional). E-GARCH model also revealed asymmetry in volatility spill-over for almost all markets post crisis. These findings showed that past information could be used to forecast changes from one market to another thereby making these markets 'informationally inefficient'.
Arifin and Syahruddin ${ }^{23}$ investigated using a more complex bivariate VAR BEKK model, the spill-over effects between returns on the stock market and changes in the exchange rate for five countries of the ASEAN region. The period of study included two crisis periods i.e. the subprime crisis and Asian Crisis. The country specific results showed that fluctuations in the exchange rate of a country was responsible to a great extend in influencing the stock market volatility of that country. Beer and Hebein ${ }^{24}$ made an attempt to test for spill-over from stock indices to exchange rates and vice-versa for nine countries which included a mix of developed and developing economies. The methodology adopted was E-GARCH for spillover and Johansen Co-integration for inter-linkages. The Johansen test proved that no-co-integration existed between the two variables for six out of nine countries. E-GARCH test however showed some positive spill-overs from the foreign exchange markets to stock market in case of five of the six countries which were included in the sample. Further persistence of volatility as shown by the sum of alpha and beta was more pronounced in emerging economies than developed markets.

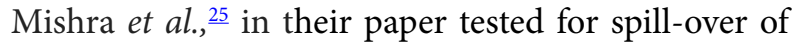
volatility between stock and foreign exchange markets using AR (1)-GARCH and AR (1)-E-GARCH Models. The results of the study showed an existence of bi-directional volatility spill-over between the two markets thus showing that the flow of information between two markets was predictable with some indication of their integration. E-GARCH results also showed asymmetric impact of a shock or innovation. Qayyum and Kemalles made an attempt to study co-integration between foreign exchange and stock markets of Pakistan using two step Engle-Granger Co-integration Model. They also tested for spill-over using E-GARCH Model. The results showed no long term co-integration, however returns of spill-over showed that both markets impacted each other in terms of volatility. Again E-GARCH methodology was also used to explore spill-over in the study done by Yang and Doong ${ }^{27}$ for G-7 countries. The study investigated spillover with respect to both mean and volatility and the results showed stock prices were impacting movements in exchange rate, however vice versa could not be found in the study. In terms of country specific results, significant volatility spill-overs with asymmetric effects from stocks to exchange rate were observed in Italy, France, Japan and US. The flow of information clearly suggested that two markets were integrated in these countries. 
Nath and Samanta $\mathrm{a}^{28}$ failed to detect any inter-linkages between daily returns on Nifty Index and daily changes on Rupee Dollar Exchange Rate for the period March 1993 to Dec. 2002. The methodology adopted was Granger Causality and Johansen's (1991) ML Co-integration test procedures. Although consolidated and yearly results showed no inter-linkages, during the latter period, stock returns were influencing changes in exchange rate in causal manner with an indication of mild influence in the opposite direction. A more specific study was carried out by Apte ${ }^{29}$ to check the spill-over effect using E-GARCH Methodology. The study too sampled Indian Markets and the entire period of study was broken down between period before and after opening up of markets to foreign investment. The results showed that there was spill-over from foreign exchange to stocks before the market was opened, however the study could not find such an effect after opening up of the markets.

\section{Sources of Data}

The period of the study under consideration is ten financial years from April 2007-March 2017 and the data has been collected as monthly closing prices of the two variables namely rupee dollar exchange rate and Nifty Index. The data sources include websites of BSE (www.bseindia.com) and NSE (nseindia.com) ${ }^{30}$. The analysis has been carried out at first differenced (log transformed) data i.e. $\ln$ (Pt/Pt-1), which converts the variable to $\log$ return. The primary reason for using $\log$ is the assumption of log normality of financial data. The statistical and econometric tools applied in the study included (a) Augmented Dickey-Fuller (ADF) test and Kwiatkowski-Phillips-Schmidt-Shin (KPSS) test of Variable Stationarity ${ }^{31}$ (b) Breusch-Pagan-Godfrey (B-PG) Heteroscedasticity test ${ }^{32}$ (c) AR-GARCH (p,q) Models and (d) T-GARCH variant of GARCH.

\section{Methodology Adopted and Test of Hypothesis}

\subsection{Testing the Stationarity of Variables}

Stationary of a variable is one of the pre-requisites for model building and for subsequent analysis including

\footnotetext{
*The alternative hypothesis for ADF Unit root test is set out at one tail only in order to avoid the explosive process.
}

prediction. Under this section we would be discussing two techniques to test for variable stationarity, first is the Augmented Dickey Fuller (ADF) test which is popularly called the Unit Root Test and second the KwiatkowskiPhillips-Schmidt-Shin (KPSS), a non - parametric test.

\subsubsection{Augmented Dickey Fuller (ADF) Test}

The first test of stationarity which we have applied in our study is Augmented Dickey Fuller (ADF) unit root test which detects whether our variables; Nifty Index and Re/\$ exchange rate are stationary. We construct the following two equations eq. (i and ii) to achieve this objective.

$$
\begin{aligned}
& \Delta \text { Nifty Index }_{t}=\theta_{1}+\left(\theta_{2}-1\right) \text { Nifty Index } \operatorname{In}_{t-1}+ \\
& \quad+\sum_{(i=1)}^{m} \theta_{3 \mathrm{i}} \Delta \text { Nifty Index }_{t-i}+u_{1 t} \ldots \ldots \ldots \ldots \text { Eq. (i) } \\
& \begin{aligned}
\Delta \operatorname{Re} / \$_{t}= & \alpha_{1}+\left(\alpha_{2}-1\right) \operatorname{Re} / \$_{t-1} \\
& +\sum_{(i=1)}^{m} \alpha_{3 i} \Delta \operatorname{Re} / \$_{t-i}+u_{2 t} \ldots \ldots \ldots \text { Eq. (ii) }
\end{aligned}
\end{aligned}
$$

(For equation (i), the variable under consideration for testing stationarity is Nifty Index. $\Delta$ Nifty Index ${ }_{t}$ is change in Nifty Index in period $t,\left(\theta_{2}-1\right)$ is the coefficient to decide the Stationarity for our variable Nifty Index, $\sum_{(i=1)}^{m} \theta_{3 i} \Delta$ Nifty Index t-i $_{\text {. }}$ represents change in Nifty Index in period $t-i$; ' $i$ ' represents the number of lags used. The variable $\Delta$ Nifty Index $_{t-1}$ is also called the augmented variable as this has been added to our stationary equation to take care of serial-correlation which also impacts stationarity of a variable. This term $\Delta$ Nifty Index ${ }_{t-1}$ adds up ' $\mathrm{m}$ ' times/no. of lags till the serial-correlation is removed from our equation and finally we have $\mathrm{u}_{1 \mathrm{t}}$ which is the random error term. The stationary equation for our second variable $\mathrm{Re} / \$$ is constructed on similar grounds using explanation given for earlier equation i.e. eq. (i))

The hypothesis under our Stationarity test for our Variable Nifty Index (eq. (i)) would be

Null Hypothesis $\left(\mathrm{H}_{0}\right): \theta_{2}-1=0$ or $\theta_{2}=1$

(Nifty Index is not stationary)

Alt. Hypothesis $\left(\mathrm{H}_{\mathrm{a}}\right)^{*}: \theta_{2}-1<0$, (Nifty Index is stationary)

\subsubsection{KPSS Kwiatkowski-Phillips-Schmidt-Shin (KPSS)}

The second test used under the study to detect stationarity of time series is KPSS. KPSS is a non-parametric test and 
researchers commonly use it as an additional test for stationarity of variables. The reason for its popularity is that this KPSS test follows an altogether different class of hypothesis i.e. Null Hypothesis reflects the presence of a trend in the stationary equation while the Alternative Hypothesis denotes that time series has a unit root. If the Null Hypothesis gets rejected, it would imply the existence of unit root. On the other hand if null is accepted, we come to the conclusion that there is presence of a trend (or nonstationarity due to a trend variable or trend stationary). Thus under KPSS test acceptance of Null is a good sign as presence of a trend in time series is mean-reverting, while a series which has a stochastic root has a permanent impact on the mean which is not reverting. The reason why many researchers have started using both $\mathrm{ADF}$ and KPSS tests for testing stationarity is that whereas ADF would test for Stochastic Unit root (as rejection of Null), while KPSS tests for the trend $v s$. unit root (acceptance of Null implies presence of trend and absence of unit root) and in a way both tests complement each other.

The methodology under KPSS involves regressing using OLS, the in-question variable against only the trend and a constant, obtain the residuals and add (at each stage) to get partial sum of residuals $\left(\mathrm{S}_{\mathrm{t}}\right)$. In other words, this is simply summing up at each stage e.g. $S_{5}$ would mean sum of first five residuals, $\mathrm{S}_{6}$ as sum of first six residuals and so on. Thus we arrive at us the following formula:

$\mathrm{S}_{i t}=\sum_{t=1}^{n} \sum_{i=1}^{t} u_{t}(\mathrm{i}=1,2,3, \ldots \mathrm{t}, \mathrm{t}=1,2,3, \ldots \mathrm{n})$.

Next we compute an estimate of the variance of the residuals $\left(\sigma_{u_{t}}^{2}\right)$, both the computed values are then put in the formula given as under:

$\operatorname{KPSS}\left(\mathrm{u}_{t}\right)=n^{2} \sum \mathrm{S}_{i t}^{2} / \sigma_{\mathrm{u}_{t}}^{2}$, where $\sigma_{\mathrm{u}_{t}}^{2}=\frac{\sum u_{\mathrm{t}}^{2}}{\mathrm{n}-2} ; \mathrm{n}$ is the no. of observations

Null Hypothesis $\left(\mathrm{H}_{0}\right)$ : Nifty Index has a presence of trend

Alt. Hypothesis $\left(\mathrm{H}_{\mathrm{a}}\right)$ : Nifty Index has a unit root

Decision Criteria: Null of KPSS $\left(u_{t}\right)$ is accepted if computed value of KPSS $\left(u_{t}\right)$ is lower than the critical.

\subsection{Test for Heteroscedasticity of Variables}

Heteroscedasticity or unequal variance of the error term also disturbs model building and therefore must be taken care of. To detect heteroscedasticity we would be using the popular B-P-G test, the steps of which are given as under:

\subsubsection{Breusch-Pagan-Godfrey (B-P-G) Test for} Heteroscedasticity

The B-P-G Heteroscedasticity test is carried out by following three steps:

1. For the regression $Y_{t}=\theta_{1}+\theta_{2} X_{2 t}+\theta_{3} X_{3 t}+\ldots . .+\theta_{k} X_{k t}$ $+\mathrm{u}_{t}$ obtain the residuals. (' $\mathrm{k}$ ' is the no. of lags for our regression, ' $t$ ' is the time period)

2. Square these residuals and run an auxiliary regression with dependent variable as squared residuals and independent variables as in original regression i.e. $u_{t}^{2}=\theta_{1}+\theta_{2} X_{2 t}+\theta_{3} X_{3 t}+\ldots . .+\theta_{k} X_{k t}$ Obtain $R$ Square of this equation.

3. $\mathrm{BPG}$ is given by $\mathrm{n} \cdot \mathrm{R}_{\text {aux }}^{2} \sim \chi_{\mathrm{m}-1}^{2}$, if computed value is higher than table value, reject Null of No Heteroscedasticity. (' $n$ ' is number of observations)

\subsection{Test for Spill-over of Volatility}

\subsubsection{GARCH $(p, q)$ Methodology for Checking the Spill-over Between Re/\$ Exchange Rate and Nifty Index}

Spill-over of Volatility from Re/\$ exchange rate to Nifty Index and vice-versa is examined by applying GARCH $(\mathrm{p}, \mathrm{q})$ methodology. The first step here is to specify the model i.e. (a) mean equation (b) behaviour of the error term (c) equation for variance of the error term. While applying GARCH $(\mathrm{p}, \mathrm{q})$ methodology we try to establish conditional variance models under different lag structures with maximum lag fixed at ' 2 '. For Spill-over, we establish two models, Model I (eq. iii and iv) where spill-over is identified as moving from Re/\$ exchange rate to Nifty stock market index and Model II (eq. v and vi), where spill-over is identified as moving from Nifty Index to $\mathrm{Re} / \$$ exchange rate. The spill-over term; $\mathbf{v}_{(\mathrm{s}), \mathbf{t}}^{2}$ or $\mathbf{u}_{(\mathrm{s}), \mathrm{t}}$ as may be the case, shall be standardized squared residuals from other market and included as variance regress or, assuming contemporaneous relation.

\section{Model I}

Mean Equation: Ret Nifty Index $x_{t}=$

$\theta_{1}+\theta_{2}$ Ret Nifty Index ${ }_{t-1}+u_{t} \ldots \ldots \ldots \ldots \ldots . .$. Eq. (iii)

$\mathrm{u}_{\mathrm{t}} \sim \operatorname{iid~} \mathrm{N}\left(0, \sigma^{2} \mathrm{u}_{\mathrm{t}}\right)$

Variance Eq.: $\mathrm{h}_{\mathrm{t}}$ (Ret Nifty Index) $=$

$\pi_{1}+\pi_{2} \mathrm{u}_{\mathrm{t}-1}^{2}+\pi_{3} \mathrm{~h}_{\mathrm{t}-1}+\pi_{4} \mathrm{v}_{(\mathrm{s}), \mathrm{t}}{ }^{2} \ldots \ldots \ldots \ldots \ldots \ldots$ Eq. (iv) 


\section{Model II}

Mean Equation: Ret Exch. Rate $_{\mathrm{t}}=$ $\alpha_{1}+\alpha_{2}$ Ret Exch. Rate ${ }_{\mathrm{t}-1}+\mathrm{v}_{\mathrm{t}} \ldots \ldots \ldots \ldots \ldots$ Eq. (v)

$\mathrm{v}_{\mathrm{t}} \sim \operatorname{iid} \mathrm{N}\left(0, \sigma^{2} \mathrm{v}_{\mathrm{t}}\right)$

Variance Eq. ${ }^{*} \mathrm{~h}_{\mathrm{t}}($ Ret. Exch. Rate $)=$

$\beta_{1}+\beta_{2} \mathrm{v}_{\mathrm{t}-1}^{2}+\beta_{3} \mathrm{u}_{(\mathrm{s}) \mathrm{t}}^{2} \ldots \ldots \ldots \ldots \ldots \ldots \ldots \ldots$ Eq. (vi)

[ ${ }^{*}$ Note: In Eq. $(v i)$, coefficient of GARCH term $\left(h_{t-1}\right)$ shall be zero as our best identified model is ARCH (1)]

\subsection{Test for Asymmetry in Volatility and Spill-over (Asymmetric Spill-over)}

\subsubsection{T-GARCH $(p, q)$ Methodology for Checking the Asymmetric Spill-over in Return Volatility}

To check for the asymmetry in return volatility i.e. differential impact of a positive shock and a negative shock on volatility of returns we introduce Threshold GARCH or T-GARCH Model. This is done by simply adding a dummy variable (multiplicative dummy) in the variance equation. Dummy $\left(\mathrm{D}_{1}\right.$ or $\mathrm{D}_{2}$ included in eq. (viii) and (ix) as may be the case) is assumed to take the value ' 1 ', if error term $\left(u_{t}\right.$ or $v_{t}$ as may be the case) is negative and ' 0 ' otherwise. The bad news therefore has an impact of ' $\pi_{1}+\gamma_{2}$ ' (see Model III eq. viii) or ' $\pi_{2}+\alpha_{2}$ ' (see Model IV, eq. $\mathrm{x}$ ), while good news has an impact of either ' $\pi_{1}$ ' (Model III) or ' $\pi_{2}$ ' (Model IV). It is important that the Dummy must be significant else the impact becomes symmetric. For two models, Model III and Model IV, the mean equation is synonymous with Model I and II respectively while the variance equation in addition includes the T-GARCH term. The spill-over term is also included and therefore the term asymmetric spill-over. The two models are given as under:

\section{Model III}

Mean Equation: Ret Nifty Index ${ }_{t}=$ $\lambda_{1}+\lambda_{2}$ Ret Nifty Index ${ }_{\mathrm{t}-1}+u_{t} \ldots \ldots \ldots \ldots \ldots$ Eq. (vii)

$u_{t} \sim \operatorname{iid} \mathrm{N}\left(0, \sigma^{2} u_{t}\right)$

Variance Equation $h_{t}($ Ret Nifty Index $)=$ $\gamma_{1}+\left(\pi_{1}+\gamma_{2} D_{1}\right) u_{\mathrm{t}-1}^{2}+\gamma_{3} h_{\mathrm{t}-1}+\gamma_{4} \mathrm{v}_{(s), t}^{2} \ldots \ldots \ldots$ Eq. (viii)

\section{Model IV}

Mean Equation: Ret Exch. Rate ${ }_{\mathrm{t}}=$

$\psi_{1}+\psi_{2}$ Ret Exch. Rate ${ }_{\mathrm{t}-1}+\mathrm{v}_{\mathrm{t}}$

$\mathrm{v}_{\mathrm{t}} \sim \operatorname{iid} \mathrm{N}\left(0, \sigma^{2} \mathrm{v}_{\mathrm{t}}\right)$

Variance Eq.*: $\mathrm{h}_{\mathrm{t}}($ Ret Exch. Rate $)=$

$\alpha_{1}+\left(\pi_{2}+\alpha_{2} \mathrm{D}_{2}\right) \mathrm{v}_{\mathrm{t}-1}^{2}+\alpha_{3} \mathrm{u}^{2}{ }_{(\mathrm{s}), \mathrm{t}}$

$\left[{ }^{*}\right.$ Note: In Eq. (x), coefficient of GARCH term (ht-1) shall be zero as our best identified model is ARCH (1)]

\section{Empirical Results}

Under this section we discuss the empirical results of the study which are given in tabular format (Tables 1 to 5). The first table, Table 1 gives the results of ADF unit root test for both the variables at level and $1^{\text {st }}$ difference with computed $\mathrm{ADF}$ ' $\mathrm{t}$ ' values, test critical values at $5 \%$ levels and corresponding ' $\mathrm{p}$ ' values. The results clearly point out that both the variables Exchange Rate and Nifty Index are stationary only at $1^{\text {st }}$ difference for both the variables, ' $\mathrm{t}$ ' values computed in absolute terms from the slope coefficients are higher than the absolute critical values of the ADF statistic at $5 \%$ level.

In order to augment the power of the ADF test, especially when it comes to accepting the Null Hypothesis (i.e. the test may incorrectly interpret a stationary variable as non- stationary) it was decided to carry out a second stationarity test, the KPSS test of stationarity. The KPSS test as already discussed follows a different set of hypothesis with the Null as trend stationary and the alternative as unit root time series. In simple words, on one side of the coin we have non stationary due to trend and on the other side we have non stationary due to unit root. The results of the KPSS test are given in Table 2 below. The results reveal that both the variables are accepting the Null at $1^{\text {st }}$ difference (the computed LM values of both the variables are lower than the critical values at both $5 \%$ and $1 \%$ levels). Again as already stated above, acceptance of Null under KPSS means time series is trend stationary which is not a major problem and therefore we may proceed with further data analysis using first differenced (return) variable.

After the results of stationarity tests of our variables, next set of results pertain to Heteroscedasticity which have been computed using B-P-G Test methodology. These results are given in Table 3 below. 
The null hypothesis for the B-P-G test is Homoscedasticity (the variable does not suffer from Heteroscedasticity), however the results revealed that both our variables, Nifty Index and Re/\$ Exchange Rate were rejecting the Null Hypothesis as the 'p' values of F statistics (as well as Observed $\mathrm{R}$ Square) were highly significant thereby rejecting the null of homoscedasticity. Now since our time series showed the presence of Heteroscedasticity, we established an ARCH/GARCH Model whose results are displayed in Table 4 (a) and (b) below.

Under ARCH MLE Model approach, to obtain the optimal model we tested models with different lags of $\mathrm{ARCH}$ and GARCH on our data and these include $\operatorname{ARCH}(1), \operatorname{ARCH}(2), \operatorname{GARCH}(1,1), \operatorname{GARCH}(2,1)$ and GARCH(2,2) Models. The optimal model for both the variables has been selected by considering the ' $\mathrm{p}$ ' values of $\mathrm{ARCH}$ and $\mathrm{GARCH}$ terms from our $\mathrm{ARCH}$ MLE Regression. Further the same model has been extended to incorporate the spill-over effects for which we have introduced standardized squared residuals (contemporaneous) as variance regress or in our ARCHGARCH models. For standardizing the residuals, assume $e_{t}$ to be the residual which is to be standardized as $e_{(s), t^{\circ}}$ then standardized residuals have been obtained by applying the formula $e_{(s), j, t}=\frac{e_{j, t}-\overline{e_{j, t}}}{\sigma_{\boldsymbol{e}_{i, t}}}$; where $e_{j, t}$ is the

Table 1. ADF (Unit root) Test Results of our Variables

\begin{tabular}{|l|l|l|l|}
\hline Null Hypothesis & $\begin{array}{l}\text { Augmented } \\
\text { Dickey- } \\
\text { Fuller test } \\
\text { statistic } \\
\text { computed } \\
\text { 't' values }\end{array}$ & values' & $\begin{array}{l}\text { Null Accept/ } \\
\text { Reject }\end{array}$ \\
\hline $\begin{array}{l}\text { Exchange Rate } \\
\text { has a unit root at } \\
\text { level }\end{array}$ & -0.69171 & 0.8439 & Accept \\
\hline $\begin{array}{l}\text { Exchange Rate } \\
\text { has a unit root } \\
\text { (1t diff) }\end{array}$ & -10.3635 & 0.0000 & Reject \\
\hline $\begin{array}{l}\text { Nifty Index has a } \\
\text { unit root at level }\end{array}$ & -0.87371 & 0.7935 & Accept $^{* 1}$ \\
\hline $\begin{array}{l}\text { (Nifty Index has } \\
\text { a unit root (1 } \\
\text { diff }\end{array}$ & -10.8148 & 0.0000 & Reject $^{* 1}$ \\
\hline
\end{tabular}

Note: ${ }^{\star} 1$ Rejected when compared to Critical Values for ADF Unit root test at $5 \%$ level $(-2.885863)$.

Source: Authors' own computation. residual of the ' $\mathrm{j}$ 'th variable for time period ' $\mathrm{t}$ ' $\overline{e_{j, t}}$ is the mean of the residuals of the ${ }^{~} \mathrm{j}^{\text {th }}$ variable for the same time period while $\sigma_{e_{i,}}$ is the standard deviation of the residuals of the ' $j$ 'th variable for period ' $t$.' Also if our ARCH Model has been set up using Exchange Rate, then the variance regress or included is the standardized squared residuals of the other variable (i.e. NSE Nifty) and vice-versa.

Speaking of the results obtained from ARCH-GARCH Models, we find that when the variable is exchange rate ( $\mathrm{Re} / \$)$, the ARCH (1) Model is the most optimal as it has a 'p' value of 0.0234 (Table 4(a)). The 'p' value increases as we go with the ARCH (2) Model ('p' value of 0.0910) and even GARCH $(1,1)$ which has ' $p$ ' value of the GARCH term as insignificant.

Table 4(b) gives the results of ARCH-GARCH Models for our second variable Nifty Index and we find that the optimal model is the GARCH $(1,1)$ model with a ' $p$ ' value of 0.0494 for ARCH (1) term and 0.0371 for GARCH(1) term.

The last column of Table 4(a) and (b) gives the results of spill-over (standardized squared residuals) and for the models identified as optimal, we find that spill-over occurs both ways (bilateral) from Exchange Rate to Nifty Index and also vice versa as given by the significant ' $p$ ' values in both the cases.

Table 2. KPSS (trend stationary) Test Results of our Variables

\begin{tabular}{|l|l|l|}
\hline Null Hypothesis & $\begin{array}{l}\text { Kwiatkowski- } \\
\text { Phillips-Schmidt- } \\
\text { Shin test statistic } \\
\text { computed LM values }\end{array}$ & $\begin{array}{l}\text { Null Accept/ } \\
\text { Reject }\end{array}$ \\
\hline $\begin{array}{l}\text { Exchange Rate } \\
\text { ( Level) has a } \\
\text { deterministic trend }\end{array}$ & 1.2216 & Reject $^{* 2}$ \\
\hline $\begin{array}{l}\text { Exchange Rate } \\
\left(1^{\text {st }} \text { diff) has a }\right. \\
\text { deterministic trend }\end{array}$ & 0.0771 & Accept $^{* 3}$ \\
\hline $\begin{array}{l}\text { Nifty Index ( Level) } \\
\text { has a deterministic } \\
\text { trend }\end{array}$ & 1.0968 & Reject $^{* 2}$ \\
\hline $\begin{array}{l}\text { Nifty Index ( } 1^{\text {st }} \text { diff) } \\
\text { has a deterministic } \\
\text { trend }\end{array}$ & 0.0565 & Accept $^{* 3}$ \\
\hline
\end{tabular}

Note: Critical Values for KPSS test: 5\%: 0.463000 and $1 \% 0.739000$

${ }^{*} 2$ Rejection of Null shows presence of stochastic root.

*3 Acceptance of Null would mean there is absence of stochastic unit root but has a trend.

Source: Authors' own computation. 
Table 3. Results of the BPG Heteroscedasticity Tests

\begin{tabular}{|l|c|c|l|l|}
\hline Variable & $\begin{array}{c}\text { 'p' value of F } \\
\text { Statistics(1,117) }\end{array}$ & $\begin{array}{c}\text { 'p' value of Observed R } \\
\text { Square (Chi Square) }\end{array}$ & \multicolumn{1}{|c|}{ Null Hypothesis } & \multicolumn{1}{|c|}{ Result } \\
\hline $\begin{array}{l}\text { Exchange } \\
\text { Rate }(\text { Re/\$) }\end{array}$ & 0.0446 & 0.0443 & No Heteroscedasticity & $\begin{array}{l}\text { Heteroscedasticity exists, } \\
\text { Introduce ARCH }\end{array}$ \\
\hline NSE Nifty & 0.0554 & 0.0548 & No Heteroscedasticity & $\begin{array}{l}\text { Heteroscedasticity exists, } \\
\text { Introduce ARCH }\end{array}$ \\
\hline
\end{tabular}

Source: Authors' own computation.

Table 4. GARCH (p,q) Model along with Spill-over Results between Re/\$ Exchange Rate and NSE Nifty

Table 4(a). Dependent Variable: Exchange Rate

\begin{tabular}{|l|c|c|c|c|}
\hline Model & $\begin{array}{c}\text { 'p' value of ARCH(1) } \\
\text { term coefficient }\end{array}$ & $\begin{array}{c}\text { 'p' value of ARCH(2) } \\
\text { term coefficient }\end{array}$ & $\begin{array}{c}\text { p' value of GARCH(1) } \\
\text { term coefficient }\end{array}$ & $\begin{array}{c}\text { Variance Regressor } \\
\text { (std. squared residuals) }\end{array}$ \\
\hline ARCH(1) & 0.0234 & - & - & 0.0010 \\
\hline ARCH(2) & 0.0910 & 0.1225 & - & 0.0652 \\
\hline GARCH(1,1) & 0.0965 & - & 0.1203 & 0.4466 \\
\hline GARCH(2,1) & 0.1777 & 0.1741 & 0.2560 & 0.1164 \\
\hline
\end{tabular}

Source: Authors' own computation.

Table 4(b). Dependent Variable: NSE Nifty

\begin{tabular}{|l|c|c|c|c|c|}
\hline Model & $\begin{array}{c}\text { 'p' value of } \\
\text { ARCH(1) term } \\
\text { coefficient }\end{array}$ & $\begin{array}{c}\text { 'p' value of } \\
\text { ARCH(2) term } \\
\text { coefficient }\end{array}$ & $\begin{array}{c}\text { p' value of } \\
\text { GARCH(1) term } \\
\text { coefficient }\end{array}$ & $\begin{array}{c}\text { p' value of } \\
\text { GARCH(2) term } \\
\text { coefficient }\end{array}$ & $\begin{array}{c}\text { Variance Regressor } \\
\text { (std. squared } \\
\text { residuals) }\end{array}$ \\
\hline ARCH(1) & $\mathbf{0 . 0 2 5 5}$ & - & - & - & 0.0421 \\
\hline ARCH(2) & $\mathbf{0 . 0 3 2 2}$ & $\mathbf{0 . 0 3 6 3}$ & - & - & 0.9185 \\
\hline GARCH(1,1) & $\mathbf{0 . 0 4 9 4}$ & - & $\mathbf{0 . 0 3 7 1}$ & - & $\mathbf{0 . 0 6 7 0}$ \\
\hline GARCH(2,1) & $\mathbf{0 . 0 5 8 1}$ & $\mathbf{0 . 0 9 7 9}$ & $\mathbf{0 . 0 0 5 4}$ & - & $\mathbf{0 . 0 4 9 9}$ \\
\hline GARCH(2,2) & $\mathbf{0 . 0 5 8 8}$ & $\mathbf{0 . 1 0 8 6}$ & $\mathbf{0 . 0 7 5 9}$ & 0.4216 & 0.0669 \\
\hline
\end{tabular}

Source: Authors' own computation.

Table 5. T-GARCH (p,q) Asymmetric Spill-over Results between Re/\$ Exchange Rate and NSE Nifty

\begin{tabular}{|l|l|l|l|}
\hline $\begin{array}{l}\text { Dep. } \\
\text { Variable }\end{array}$ & Model Selected & $\begin{array}{l}\text { 'p' value of } \\
\text { RESID }(-1)^{\wedge} 2^{*} \\
(\operatorname{RESID}(-\mathbf{1})<0)\end{array}$ & $\begin{array}{l}\text { Asymmetry } \\
(\text { Yes/No })\end{array}$ \\
\hline $\begin{array}{l}\text { Exchange } \\
\text { Rate }\end{array}$ & $\begin{array}{l}\text { ARCH(1), } \\
\text { T-GARCH(1) }\end{array}$ & 0.5333 & No \\
\hline NSE Nifty & $\begin{array}{l}\text { GARCH }(1,1), \\
\text { T-GARCH }(1)\end{array}$ & 0.2309 & No \\
\hline
\end{tabular}

Source: Authors' own computation.

The last set of results pertains to asymmetry tests for which we include in our optimal model the Threshold GARCH or T-GARCH (1) term (see Table 5).
The results which are of our interest are the ' $\mathrm{p}$ ' value of the term $\operatorname{RESID}(-1)^{\wedge} 2^{*}(\operatorname{RESID}(-1)<0)$ in Table 5 which is the coefficient for testing the asymmetry (asymmetry in terms of return volatility of a variable due to the leverage impact of a positive and negative news). The results of the 'p' statistics of this asymmetry coefficient accepts the null hypothesis for both the variables thereby confirming that there is no asymmetry in volatility of returns of our two variables.

\section{Conclusion and Policy Recommendations}

The present study aimed at modelling the conditional volatility of returns (i.e. volatility of returns changing 
over time) of the two Indian financial markets viz. Re/\$ Exchange Rate and Nifty Index Stock Index of the National Stock Exchange of India. The methodology employed was GARCH (p,q) with different variants and the main focus of the paper was on identifying the optimal volatility model and also to determine whether there was any spill-over of volatility from one market to another. To achieve this specific objective, a variable 'standardized squared residuals from another market' was added as an independent variable in the volatility model. Another aim of the paper was to find out whether or not there was any asymmetry in volatility of returns of the two markets under study. This was achieved by incorporating; Threshold GARCH Model (T-GARCH) in the volatility structure. The results of the study could identify conditional volatility of returns and the optimal model as identified was ARCH (1) for Re/\$ Exchange Rate and GARCH $(1,1)$ for Nifty Index. The spill-over results showed bi-directional volatility spill-over as captured by the variance regress or, the standardized squared residuals. Further, unlike most studies where negative news was proven to cause higher volatility than positive news, in the present study, the results could not provide any evidence of this asymmetry in volatility as the T-GARCH coefficient was not significant for both the markets under study.

The results of the study brings to light some useful information for the policy makers and portfolio investors; first the information transmission between the two markets viz. Re/\$ foreign exchange market and Stock Market of India cannot be denied due to the bi-directional spill-over which was proved through our study results. This would simply mean that information of one of these markets can influence and also be used as a forecasting tool (for prediction) in another market. Such an information could be extremely useful for portfolio investors especially those who would like to achieve their twin objective of asset allocation and diversification of their funds. Such managers in order to minimize risk, could ideally select either of these two markets (usually one which gives more return for a level of risk) in their portfolio and avoid big exposures to both markets in their portfolio. Further, the fact that asymmetric returns could not be proved in any of the two markets would provide a big consolation for those portfolio investors/managers who just refrain from taking exposure to a market, because of a general feeling that even a small bad news would result in massive fall in markets.

\section{References}

1. Kim K. Dollar Exchange Rate and Stock Price: Evidence from Multivariate Co-integration and Error Correction Model. Review of Financial Economics. 2003; 12(3):301313. https://doi.org/10.1016/S1058-3300(03)00026-0

2. King MA and Wadhwani S. Transmission of Volatility between Stock Markets. The Review of Financial Studies. 1990; 3(1):5-33. https://www.jstor.org/stable/2961954

3. Balli F, Hajhoj HR, Basher SA and Ghassan H. B. An analysis of returns and volatility spill-overs and their determinants in emerging Asian and Middle Eastern countries. International Review of Economics and Finance. 2015; 39:311-325. https://doi.org/10.1016/j.iref.2015.04.013

4. Hilliard JE. The relationship between equity indices on world exchanges. Journal of Finance. 1979; 34(1):103-114. https://www.jstor.org/stable/2327147

5. Dornbusch R and Fischer S. Exchange rates and the current account. The American Economic Review. 1980; 70(5):960971. https://www.jstor.org/stable/1805775

6. Branson WH. A model of exchange-rate determination with policy reaction: evidence from monthly data. 1983. https://doi.org/10.3386/w1178

7. Frankel JA. Monetary and portfolio balance models of exchange rate determination. In: Bhandari, J.S., Putnam, B.H. (Eds.). Economic Interdependence and Flexible Exchange Rates. MIT Press, Cambridge, MA; 1983.

8. Solnik B. Using financial prices to test exchange rate models: A note. The journal of Finance. 1987; 42(1):141-149.

9. Kutty G. The relationship between exchange rates and stock prices: the case of Mexico. North American Journal of Finance and Banking Research. 2010; 4(4):1-11.

10. Aggarwal R. Exchange Rates and Stock Prices: A Study of the US Capital Markets under Floating Exchange Rates. Akron Business and Economic Review. 1981; 12(3):7-12.

11. Soenen L. and Hennigar E. An Analysis of Exchange Rates and Stock Prices: The US Experience between 1980 and 1986. Akron Business and Economic Review. 1988; 19:7-16.

12. Bahmani-Oskooee $M$ and Sohrabian A. Stock Prices and the Effective Exchange Rate of the Dollar. Applied Economics. 1992; 24(4):459-464. https://doi.org/10.1080/ 00036849200000020

13. Ajayi RA and Mougoue M. On the Dynamic Relation between Stock Prices and Exchange Rates. Journal of Financial Research. 1996; 19(2):193-207. https://doi. org/10.1111/j.1475-6803.1996.tb00593.x

14. Ajayi RA, Friedman J and Mehdian SM. On the Relationship between Stock Returns and Exchange Rates: Tests of Granger Causality. Global International Journal of Business and Economics. 1998; 9(2):241-251. https://doi. org/10.1016/S1044-0283(98)90006-0 
15. Nieh CC and Lee C-F. Dynamic Relationships between Stock Prices and Exchange Rates for G-7 Countries. Quarterly Review of Economics and Finance. 2001; 41(4):477-490.

16. Engle RF. Autoregressive conditional heteroscedasticity with estimates of the variance of United Kingdom inflation. Econometrica: Journal of the Econometric Society. 1982; 50(4):987-1007. https://www.jstor.org/stable/1912773

17. Bollerslev T. Generalized autoregressive conditional heteroskedasticity. Journal of econometrics. 1986; 31(3):307-327. https://doi.org/10.1016/0304-4076(86)90063-1

18. Polisetty A. Kumar P and Kurian JS. Influence of Exchange Rate on BSE Sensex and NSE Nift. IOSR Journal of Business and Management. 2016; 18(9):10-15. Available at www.iosrjournals.org

19. Poornima DS and Ganeshwari M. Relationship between Exchange Rates and Stock Market Index: Evidence from the Indian Stock Market. International Journal of Science and Research (IJSR). 2016; 5(10):16-18.

20. Agrawal G, Srivastav AK and Srivastava A. A study of exchange rates movement and stock market volatility. International Journal of Business and Management. 2010; 5(12):62-73. https://doi.org/10.5539/ijbm.v5n12p62

21. Gulati D and Kakhani M. Relationship between stock market and foreign exchange market in India: An empirical study. Pacific Business Review International. 2012; 5(5): 66-71.

22. Mozumder N, De Vita G, Kyaw S and Larkin C. Volatility spill-over between stock prices and exchange rates: New evidence across the recent financial crisis period. Economic Issues. 2015; 20(1):43-64.

23. Arifin, J and Syahruddin N. Volatility spill-overs between equity and currency markets in ASEAN-5 countries during crises. In Proceedings of 13th International Conference on
Banking and Finance: Lessons Learned from the Financial Crises. 2011; 12:13-22.

24. Beer F and Hebein F. An Assessment of the stock market and exchange rate Dynamics in industrialized and emerging markets. International Business and Economics Research Journal. 2008; 7(8):59-70. https://doi.org/10.19030/iber.v7i8.3283

25. Mishra AK, Swain N and Malhotra DK. Volatility spillover between stock and foreign exchange markets: Indian evidence. International Journal of Business. 2007; 12(3):343-359.

26. Qayyum A and Kemal AR. Volatility Spill-over between the Stock Market and the Foreign Market in Pakistan. Working Papers and Research Reports. 2006

27. Yang SY and Doong SC. Price and volatility spill-overs between stock prices and exchange rates: empirical evidence from the G-7 countries. International Journal of Business and Economics. 2004; 3(2):139-153.

28. Nath, GC and Samanta GP. Dynamic relation between exchange rate and stock prices: a case for India. In 39th Annual Conference paper of Indian Econometric Society also published in NSE News; 2003 February.

29. Apte, P. The interrelationship between the stock markets and the foreign exchange market. 2001. Available at https:// papers.ssrn.com/sol3/papers.cfm

30. Websites for data: BSE(www.bseindia.com), NSE(nseindia. com)

31. Shin Y and Schmidt P. The KPSS stationarity test as a unit root test. Economics Letters. 1992; 38(4):387-392. https:// doi.org/10.1016/0165-1765(92)90023-R

32. Breusch TS and Pagan AR. A simple test for heteroscedasticity and random coefficient variation. Econometrica: Journal of the Econometric Society. 1979; 47(5):1287-1294. https://www.jstor.org/stable/1911963 